\title{
It Happened on the First September (or Whenever) (Stalo sa prvého septembra [alebo inokedy])
}

Author: Pavol Rankov

First Published: 2008

Translations: Czech (Stalo se prvního zář́ [nebo někdy jindy], 2010); Croatian (Dogodilo se prvoga rujna [i ne samo tada], 2011); Hungarian (Szeptember elsején [vagy máskor], 2011); Bulgarian (Sluči se na prvi septemvri [ili v drug den], 2013); Polish (Zdarzyło się pierwszego września [albo kiedy indziej], 2013); German (Es geschah am ersten September [oder ein andermal], 2014), Macedonian (Se sluči na prvi septemvri [ili nekoj drug den], 2014); Romanian (S-a intamplat la intai septembrie [sau altcandva], 2016); Italian (Accadde il primo settembre [o un altro giorno], 2017); French (C'est arrivé un premier septembre, 2019).

Theatre Adaptation: Slovenské národné divadlo (Slovak National Theatre), Bratislava (2010); Divadlo v Dlouhé (Theatre in Dlouhá Street), Prague (2011).

About the Author: Pavol Rankov (1964) is a Slovak writer and scientist. He was born in Poprad and studied library science at Comenius University in Bratislava, graduating in 1987. He worked at the Slovak National Library in Martin and at the Slovak Pedagogical Library in Bratislava. In 1993, he joined the staff of the Comenius University in Bratislava where he researches mass communication and media.

Further Important Publications: $S$ odstupom času (1995, Over the Distance of Time; short stories); My a oni / Oni a my (2001, Us and Them; short stories); V tesnej blizkosti (2004, Close Up; short stories); Matky (2011, Mothers; novel); Poviedky (2012, Short Stories; all three short stories books).

\section{Content and Interpretation}

Rankov's novel describes three decades of Slovakia's and Central Europe's past, from 1938 to 1968. It is divided into 31 chapters, always named after one year, the first is Episode 1938 and the last one Episode 1968. The events begin on September 1st, 1938, a year before World War II, and they are often concentrated on the first of September.

In 1938, the four main characters are 13-year-old. There are three boys and one girl living in the small town of Levice in south Slovakia. They belong to different ethnicities: the Hungarian Peter Rónai, the Czech Jan Bízek, the Jew Gabriel Rosenberg and the Slovak girl Mária (Mary) Belajová. All the boys fall in love with Mária and compete for her favour. 
Political events significantly affect the lives of the characters. In November 1938, Levice becomes a part of Hungary and Jan's family moves to the Moravian city of Brno. During the war, Peter and his brother must enlist in the Hungarian army. His brother is killed on the Eastern front, and Peter deserts. Gabriel is deployed into forced labour. He manages to escape but his mother perishes in a concentration camp. Jan's parents die during an air raid. His sister becomes a lover of several German soldiers and disappears after the war. All three friends survive, nevertheless no one gets Mária.

After the war, political circumstances continue to complicate the existence of the characters. All three friends want to win and marry Mária, nevertheless, something always happens that prevents it. Levice becomes a part of the restored Czechoslovakia once again. Peter becomes an enthusiastic communist and works as a journalist. Gabriel and Jan emigrate to Palestine but later both return to Slovakia. Jan graduates with a degree in Chemistry and Technology in food studies and works in the military food institute. He is blackmailed because of his sympathy to "Zionism" and must report to the secret police. Mária graduates with a degree in Pedagogical Studies and is a teacher. In 1950, Mária and Jan arrange to get married, but Mária’s father, a communist, is arrested and imprisoned, so the wedding is canceled. The second date of their wedding is in 1956. However, Jan is sent on a trip abroad and is involved in the uprising against the Communist regime in Budapest. He flees to the United States without knowing that Mária is pregnant and will give birth to his daughter. In the 1960s, Jan becomes a rich businessman due to his invention of dried scrambled eggs, used by the U. S. Army in Vietnam.

Gabriel is treated for tuberculosis and works in the Tatra Mountains as a clerk and later as a guide. In 1961, Gabriel visits Berlin in East Germany and wants to emigrate to the West. However, at this moment the Berlin Wall is being built and he must return to Czechoslovakia.

All of the friends meet again in the last chapter in the summer of 1968, during the Prague Spring. This chapter is narrated by Mária while all the others by an impersonal narrator. After the Soviet invasion of Czechoslovakia, Jan, Peter and Gabriel leave to the West, and Mária stays in Bratislava with her daughter.

The whole plot is fictional but the novel presents historical events and real historical figures (the regent of Hungary Miklós Horthy, the Slovak president Jozef Tiso, poets Lawrence Ferlinghetti and Andrei Voznesensky, the liberal Communist politician Alexander Dubček etc.), often in grotesque situations connected with the main characters. So the everyday and intimate life (for instance erotic scenes), is depicted in a similar way to major political events (World War II, the Arab-Israeli war in 1948, the Hungarian Uprising in 1956...). The plot is full of paradoxes that also illustrate changes of the characters' names. Jan Bízek is called Honza in Brno, Ján in Slovakia and Ian in America. After the war, Peter changes his Hungarian name Rónai to Slovak Ronaj and in the time of Stalinist antisemitism Gabriel gives up his Jewish name Rosenfeld for Slovak Ruževič. 


\section{Main Topics and Problems}

The topic of the Holocaust is connected in particular with Gabriel. Immediately after the war, he interprets for the special Soviet military unit Smersh fighting against "subversive elements". They also investigate the massacres of Gypsies or Jews during the war. One of the Hungarian "nyilasi” (arrow-cross, Nazi party) reports:

"How did you kill the Jews?"

[...]

"We put them on the river-bank and shot them in the chest. Their bodies fell straight into the water, we didn't have to bury them. Later, the commander said, we had to save ammunition. So we tied the Jews up in twos or threes. We shot one but all three fell into the water. They drowned immediately".

$[\ldots]$

"Why did you do it?"

“The Jews are the Jews”, answered the nyilas. (Rankov, 2008, p. 19)

Gabriel does not feel like he is a Jew, but is affected by antisemitism, during the war and after it "He hasn't been in a synagogue, for some years, he hasn't respected Jewish customs or hold any Jewish feasts. In fact, he doesn't know any Jews in Slovakia. He only felt like a Jew whenever someone cursed the Jews”. (p. 242) While he is in the hospital due to tuberculosis in the 1950s, Gabriel speaks with an another patient, a young Catholic girl named Zuzka (Susanne) about God:

"If God would be good and merciful, he wouldn't have allowed the murdering of the Jews, His chosen nation... My mum also perished".

"I know, Gabriel, I'm sorry".

"It's possible that God didn't create this murdering. But He could have stopped it", Gabriel continued. "If He is omnipresent, as you say, he had to see it. He was present and did nothing?" (p. 141)

This motif of helplessness of God is frequently found in Holocaust literature, see Elie Wiesel's Night, Viktor Fischl's novel $\rightarrow$ Court Jesters, Otto Weiss' short story $\rightarrow$ And God Saw It Was Bad, Emil Knieža's novel $\rightarrow$ The Sixth Battalion, On Guard! or Hana Bořkovcová's novel $\rightarrow$ A Private Conversation. Pavol Rankov's nontraditional image of Slovak history aroused critical discussions. The novel It Happened on September the First (or Whenever) also using fantastic devices, like the author's short stories, belongs to the so-called posttraumatic literature, similar to Hertha Müller, Olga Tokarczuk, Radka Denemarková's $\rightarrow$ Money from Hitler, Peter Krištúfek's $\rightarrow$ Emma and the Death's Head Hawkmoth or Zyta Rudzka $\rightarrow$ Doctor Josef's Beauty.

\section{Cited Work}

Rankov, P. (2008). Stalo sa prvého septembra (alebo inokedy). Bratislava: Kalligram. 


\section{Further References}

Drastich, M. (2009). Dobrému príbehu škodí nedopovedanost'. Slovenské pohlady, 125(3), pp. 114-116. Janoušek, P. (2010). Pavol Rankov: Stalo se prvního září (anebo někdy jindy). Tvar, 21(11), p. 3. Kořená, M. (2010). Stalo se v padesátých letech (a nikdy jindy). Souvislosti, 21(3), pp. 9-11. Schacherreiter, Ch. (2015). Drei Biografien der Liebe in Zeiten der Diktatur. OÖ Nachrichten, 07.04. Available at: http://www.nachrichten. at/nachrichten/kultur/Drei-Biografien-der-Liebe-in-Zeiten-der-Diktatur;art16,1731065 [Accessed: 04.08.2019] Trávníček, J. (2010). Co uděláme s tělem, když všechny vztahy budou virtuální? Rozhovor se slovenským spisovatelem o jeho díle, současné slovenské a české literatuře a průzkumech čtenářství na Slovensku. Host, 26(4), pp. 8-12. Vaughan, D. (2012). Pavol Rankov: A Slovak Novelist Found by Czechs in Translation. Radio Prague in English, 13.10. Available at: https://www.radio.cz/en/section/books/pavolrankov-a-slovak-novelist-found-by-czechs-in-translation [Accessed: 04.08.2019]. 